\title{
The Research on the Effect of Changing Prices in the Multinational Company upon China's Economy
}

\author{
Jing Sun \\ School of Business Management, Shenyang University \\ Shenyang 110041, China \\ E-mail: sunjing9819@yahoo.com.cn
}

\begin{abstract}
With Chinese economic reformation development, more and more Multinational Corporation has invested in China. Multinational Corporation has improved the Chinese economic standards, but it has also brought negative effects, especially the changing prices in the multinational corporation. This academic paper has researched its reason, purpose and negative effect and how to take preventive measures.

Keywords: Changing price, Multinational Corporation, Negative effect

The changing price called the changing fixed price, the instigates price, internal price, it is the multinational corporation interior parent company and subsidiary company, subsidiary company and subsidiary company mutually agrees one kind of price when they export, import or purchase the product, the service and the technology. The changing price does not mean that according the supply and demand situation formulate in the international market, but artificial formulate on the basis multinational corporation's global strategy and the overall benefit. The multinational corporation interior trade involves two aspects of the commodity and the service, the changing price also includes two contents: First is the changing price of visible product, such as the company interior mutually provides price of equipment and spare parts; Second is the changing price of immaterial product, for example, the subsidiary company pay the interest of loan, fees to use the trademarks and technology to the parent company.
\end{abstract}

\section{The changing price produces background}

The changing price is the management method, which is along with the socialized mass production development and the company internal organizational form and the structure's changing.

1.1 The multinational corporation interior trade formation is the symbol and premise of the changing price production and development.

As an unification management entity which is composed by the parent company and the multitudinous overseas subsidiary company, between its parent company and the subsidiary company and the various subsidiary companies all have regularly flows of the massive funds, the commodity, the technology, the service and so on, these internal trades need to have corresponding price to take basis of calculation, therefore, the changing price can produce. Follows the enhancement with the multinational corporation's operation and management internationalization degree, in the situation of the international market existence fault of construction (for example trade protection, intellectual property rights protection and so on )and the transaction existence fault (for example extra risk, market difference),inevitably causes the company interior division to be exquisite, and corresponding to cause scale obvious expansion of company interior each essential factor and the product circulation. Only depends on the international market, to be able to affect the multinational corporation management strategy effectively implementation. Therefore, it is inevitably choose of the maximum degree using the company interior trade which is separated from to the international market.

1.2 The changing price is the method which the multinational corporation use the international tax revenue difference and other policy differences and pursues the global profit maximization.

Indicated of according to the American scholar investigation to 165 American multinational corporations, only $35 \%$ companies adopt the normal transaction price in interior transaction, but uses the no-market price is a method which the multinational corporation generally utilizes. Through this method, the multinational corporation may control many subsidiary companies which are distributing in the world obey to its global strategy goal, thus guaranteed the entire company system obtains the biggest profit.

\section{The purpose of the changing price}

\subsection{Shifts fund}

In many countries, when domestic fund and the foreign exchange relatively short, mostly adopts some limit fund shift 
measure. In particular, there have some more stringent restrictions for the foreign investors remitted their dividends and the stock dividends. At that time, the multinational corporation often through the changing price by the high price to ship out materials or provide services to the subsidiary company in this country, realization fund shifting.

\subsection{Evades tax revenue}

Mainly evade the custom and the income tax. In the aspect of custom tax, although any national company is unable to change the custom tax, but the changing price is suitable, it still might do. Usually has following two methods:

2.2.1Using the regional customs union and some certain preferential benefits stipulated of some agreements.

2.2.2Using subsidiary companies in different country (area),low delivers goods price reduction tax payment cardinal and tax payment amount, reduces the import subsidiary company importation tax. In income tax aspect, mainly use different tax rate of different country (area), for example, when multinational company sells the technology or the service from the high tax rate country to the low tax rate country, through the low price to reduce the import goods cost of the low tax rate country in order to enhance its profit. Like this, the tax rate shifts from the high tax rate country to the low tax rate country, reduce the whole tax amount of the entire company.

\subsection{Adjustment profits}

When the subsidiary company has a higher profit in the host country, it possibly can face to many problems, for example, the labor unions request to raise the host country staff wages, the host country government requests to negotiate again and so on. The multinational corporation may utilize the purchase power and the sales power which grasps, reduces the subsidiary company accounting paper profit through the changing price, and covers the actual profit, embezzles the benefit which the host country should earn.

\subsection{Reduces the quota limit}

The quota has in view of the product quantity, has in view of the product value. If in view of the product quantity, the multinational corporation may use the changing price to reduce the quota limit. For example, when the export country's subsidiary company reduce the goods price, the import country's subsidiary company need not more quota, it may increase the import product quantity.

\subsection{Obtains the competitive advantage}

When the new subsidiary company is established in overseas, the multinational corporation may through the whole company's fund power to supply the inexpensive raw material, the product and the service with using low price, and purchase the high price product of subsidiary company in order to help it sets up good prestige, and stable development. When some overseas market competition is exceptionally intense, the partner company may use the low changing price to support subsidiary company until defeat competitors, and finally seizes the market.

\section{Influencing of the multinational corporation interior changing price to China}

Indicated of the studies of importation and exportation goods price of foreign capital enterprises in China from 2001 to 2002, imported and exported 1500 kind of products in 2001, there are 124 kind of importation products price were higher than average price, highest out did $1000 \%$; and there are 428 kinds of exportation products price lower than average price, lowest price only occupied $1 \%$ on comparing average price. The foreign capital enterprises use changing price to bring many problems to China. Concentrate following several aspects:

\subsection{Chinese profit is invaded}

As for the joint capital enterprise, Chinese joint capital enterprise is on the basis of the Equity ratio to share profit, but as for the Chinese and foreign cooperative enterprise, Chinese enterprise profit according to contract, Chinese holds the certain appropriation of profit ratio. However if the foreigner implementation changing price that may cause to reduce the enterprise's profit, even appears "zero profit" and negative profit", it causes Chinese profit to reduce even loses money, but the foreign company's overall income may be increased.

\subsection{China's tax revenue income reduction}

The foreign capital enterprise's tax revenue effect is an important target of China uses foreign direct investment income. Chinese normal obtained tax rate is $33 \%$, but in order to attract the foreign enterprise investment, stipulated "the foreign capital" enterprise may enjoy the preferential benefit in tax revenue on operation in two years and reduces partly levies on the third years. The obtained tax rate is $16.5 \%$ in third year and is $33 \%$ in the sixth year. This tax rate is still higher than actual taxes of Bahamas, Hong Kong. Many foreign capital enterprises use "higher importation price and lower exportation price" to shift subsidiary company profit in China, in order to evade Chinese income tax.

\subsection{Causes China balance of payments not to be balanced}

3.3.1The changing price of "high importation price and low exportation price" can bring foreign enterprises overall profit growth. Thus, actuation foreign capital enterprise import massive product which may produce in domestic, this 
will cause Chinese importation products to increase, frequently project flowing out.

3.3.2 When foreign enterprise will buy into same the quantity commodity, the service, the technology and so on or will sell the same quantity product to the overseas related enterprise, the changing price of "high importation price and low exportation price" will cause Chinese commodity exportation will reduce and importation will increase, thus will further worsen Chinese balance of payment.

\subsection{Reduces foreign enterprise related effect of direct investment}

At present, China lacks the effective control measure to the foreign capital enterprises changing price, many foreign merchants use enterprise's importation domination, buy into many high price of raw material, the half-finished product which may produce in domestic enterprises from the overseas related enterprises, and use changing price to gain more profit. Thus, greatly decrease foreign merchants direct investment related effect.

\section{China's countermeasure upon to the multinational corporation changing price}

4.1 To study the success experience of control changing price which other countries already have, to make law which related to defend against changing price.

At present, US, Canada as well as many developing nations all very attention for control changing price, the main method which use including:

4.1.1 Tax rate integration. Levies the obtained tax rate and the customs tax from subsidiaries that make multinational corporation no matter directly collects profit or shift profit using the changing price, its real income is always same.

4.1.2 Adjust the profit. According to the ratio of the subsidiary company sales or assets which occupy the overall multinational corporation assets, estimated profit of a subsidiary to its revenue.

4.1.3 Implementation normal transaction price. Compares subsidiary company importation and exportation product price in the host country with international normal transaction price, if discovered some multinational corporation's importation product price too high or the exportation product price too low, the host country may request it make additional tax according to the normal transaction price to calculate profits

4.2 Improve Chinese technologies and the production standards to reduce the dependence degree of the foreign capital enterprise

Chinese enterprises may improve the product domestic degree to reduce the opportunity of the foreign enterprise use the changing price to shift profit.

\subsection{Consummate tax laws}

Chinese government may strengthen inspection and surveillance to the foreign capital enterprise, reduce to the possibility of international avoid taxes, may adopt the method includes:

4.3.1 Use "the formulation assignment method" to calculate the multinational corporation income tax. According to the formulation to calculate the company's profit and to levy its revenue, Chinese tax affairs department should strictly supervise the multinational corporation whole financial goals and investment behavior, if the parent company still unceasingly increase fund when the subsidiary operating worse, the tax affairs department should investigate company operation behavior, if proved its changing price and to its high quota fine.

4.3.2The customs should strengthen management to importation and exportation of the foreign capital enterprises, know each kind of commodity and service trade price, and prevent the changing price.

4.4 Improve the investments environment, positively carry on the foreign exchange system reform, and gradually realize RenMinBi free exchange. Chinese government should maintain the related laws and policies stability and continuity. Only do this, it can unceasingly promote the foreign enterprise investment motive and other behaviors rationalization, China can truly obtain the greatest income from the transnational investment.

\section{References}

Aliber,R.Z. (1970). A Theory of Direct Foreign Investment. The International Corporation, Cambridge, Mass:MIT Press. Dunning, John H. (1993). Multinational Enterprises and Global Economy. (Harrow: Addison-Wesley).

Jikang Zhang. (2004). "Transnational Corporation and Direct Investment”, Fudan University Publishing Company, China.

L. B. M. Mennes \& A. J. Stoutjesdijk, "Multinational Investment Analysis", the Johns Hopkins University.

S. H. Rock and K. Simmonds. (1989). International Business and Multinational Enterprises, pp. 261-262, $4^{\text {th }}$ edition, Homewood, H. Richard D. Irwin.

Sarah Yueting Tong. (2001). Foreign Direct Investment, Technology Transfer and Firm Performance. 